\title{
Research on the Relationship between Foreign Trade and the GDP Growth of East China-Empirical Analysis Based on Causality
}

\author{
Yuhong Li, Zhongwen Chen*, Changjian San* \\ Business School, Jinggangshan University, Ji'an, China \\ E-mail: czw922@163.com \\ Received April 19, 2010; revised June 8, 2010; accepted June 12, 2010
}

\begin{abstract}
In open economy, development of foreign trade greatly impacts GDP growth. Adopt modern testing methods like unit root, time-series co-integration analysis and error correction model for researching the causalities between foreign trade including total export and import with the collected 28-year statistical data of east China from 1981 to 2008, including total export and total import and GDP growth of east China. The result suggests that there exist long term or short termcausality between GDP and total export and import as well as between GDP and export, foreign trade is the long term and short term reason of GDP growth, but no evidence can prove that there exists long term stationary causality between import trade and GDP. This paper finally provides with some instructive recommendations on how to develop the foreign trade of east China under the new global economy environment.
\end{abstract}

Keywords: East China, GDP Growth, Foreign Trade, Causality Analysis

\section{Introduction}

Since the reform and opening up, China's foreign trade, which is playing a significance role in the world, has become more and more important. But the proportion of China's total import value in the GDP cannot match the average level of developed countries. Obviously, the foreign trade is closely related to economic growth in China. The importance of foreign trade for a country is increasingly prominent, though many researchers like Xu Qifa and Jiang Cuixia (2002) focused on the research related to the contribution of foreign trade on GDP growth, researchers particularly only focused on one region[1], a province as an example, literature related to the research on the economic development of east China is rare. Since the reform and opening up, foreign trade in east has experienced rapid development. From 1981 to 2008, exports and imports in east increased from 8.564 billion dollars to 2289.189 billion dollars. The increase of foreign trade is faster than the increase of GDP, and the proportion of foreign trade in GDP is increasing too. However, is there serious internal logical causality between GDP and foreign trade? or, is there long term or short termcausality between them? Thus, this paper will try to research and discover it.
Due to the administrative division of China (2005) and the statement of financial department about graduates going down to the grass-roots units (referring to the less developed areas of east China and the region of western China), now east China refers to the relevantly developed areas including Beijing city, Tianjin city, Shandong province, Liaoning province, Jiangsu province, Shanghai city, Zhejiang province, Fujian province and Guangdong province. However, some data of Beijing city are missing, so the data cited in this paper will not include that of Beijing city. Although it will somewhat affect the research, it will not so much impact the research of the relationship between GDP and foreign trade in east China in essence.

According to the provincial yearbooks (1981-2008), the relevant data of east China (shown as Table 1), including (1981-2008) total foreign trade value (IE), the total export value (EXP) and the total import value (IMP) as well as GDP are collected and sorted out. From the result, it could be seen that the mentioned indexes represent a trend to increase on the whole. In order to further grope for the relationship between GDP and certain index, the concept of foreign trade dependency is cited to describe it [2]. It is just the ratio of certain index of foreign trade and GDP, which can reflect the relationship of 
dependency between GDP and certain index. It can be written in a formula as,

\section{Dependence on foreign trade = certain index of foreign trade / GDP}

With the result calculated by the above formula, the dependency of each index of foreign trade represents a trend to increase on the whole, while in some years, they occasionally represented fluctuations. With the result, we could see a trend of dependency (Figure 1). The ratio of dependence on foreign trade in east increased from $12.01 \%$ in 1981 to $69.37 \%$ in 2008 . Especially, in 2006 , it reached the top $(80.88 \%)$; the ratio of dependence on export increased from $10.74 \%$ in 1981 to $43.17 \%$ in 2008 , it reached the top $(48.60 \%)$ in 2006 ; the ratio of dependence on import increased from $1.27 \%$ in 1981 to $26.2 \%$ in 2008, it reached the top (32.27\%) in 2006. These Figures intuitively indicate that each index of foreign trade of east China contributes to GDP growth at different levels. But, whether there exists internal logical causality should be further tested. Therefore, the time-series data and latest more stationary analysis methods are adopted for testing the relationships of the indexes of foreign trade and GDP of east China. We will use unit root, timeseries co-integration long term causality and short termcausality analyses to expect more stationary results [3].

Table 1. 1981-2008 relevant statistical data of GDP and foreign trade of east China.

\begin{tabular}{|c|c|c|c|c|c|c|c|}
\hline year & $\begin{array}{c}\text { GDP } \\
(100 \text { million dollars })\end{array}$ & $\begin{array}{l}\text { Foreign trade } \\
\text { (10000 dollars) }\end{array}$ & $\begin{array}{c}\text { export } \\
\text { (10000 dollars) }\end{array}$ & $\begin{array}{c}\text { import } \\
\text { (10000 dollars) }\end{array}$ & $\begin{array}{c}\text { Dependence } \\
\text { On foreign trade } \\
(\%)\end{array}$ & $\begin{array}{c}\text { Dependence } \\
\text { on export trade } \\
(\%)\end{array}$ & $\begin{array}{c}\text { Dependence } \\
\text { on import trade } \\
(\%)\end{array}$ \\
\hline 1981 & 1461.75 & 1755308 & 1569233 & 186075 & 12.01 & 10.74 & 1.27 \\
\hline 1982 & 1455.68 & 1706645 & 1517628 & 189017 & 11.72 & 10.43 & 1.30 \\
\hline 1983 & 1549.11 & 1765104 & 1540626 & 224478 & 11.39 & 9.95 & 1.45 \\
\hline 1984 & 1603.69 & 2119018 & 1699111 & 419907 & 13.21 & 10.59 & 2.62 \\
\hline 1985 & 1597.52 & 2558642 & 1793590 & 765052 & 16.02 & 11.23 & 4.79 \\
\hline 1987 & 1768.34 & 4303466 & 2675955 & 1627511 & 24.34 & 15.13 & 9.20 \\
\hline 1988 & 2317.23 & 5901747 & 3339995 & 2561752 & 25.47 & 14.41 & 11.06 \\
\hline 1989 & 2604.58 & 6692030 & 3878348 & 2813682 & 25.69 & 14.89 & 10.80 \\
\hline 1990 & 2271.60 & 7339161 & 4593243 & 2745918 & 32.31 & 20.22 & 12.09 \\
\hline 1991 & 2380.09 & 8907810 & 5342241 & 3565569 & 37.43 & 22.45 & 14.98 \\
\hline 1992 & 3022.14 & 11334101 & 6424146 & 4909955 & 37.50 & 21.26 & 16.25 \\
\hline 1993 & 4096.97 & 13560294 & 7136708 & 6423586 & 33.10 & 17.42 & 15.68 \\
\hline 1994 & 3733.62 & 16810653 & 9362583 & 7448070 & 45.03 & 25.08 & 19.95 \\
\hline 1996 & 5653.93 & 21668124 & 12217895 & 9450229 & 38.32 & 21.61 & 16.71 \\
\hline 1997 & 6342.48 & 25125789 & 14851481 & 10274308 & 39.62 & 23.42 & 16.20 \\
\hline 1998 & 6808.93 & 25955390 & 15194880 & 10760510 & 38.12 & 22.32 & 15.80 \\
\hline 1999 & 7240.87 & 29076356 & 16413372 & 12662984 & 40.16 & 22.67 & 17.49 \\
\hline 2000 & 8122.25 & 38067988 & 21040036 & 17027952 & 46.87 & 25.90 & 20.96 \\
\hline 2001 & 8974.95 & 41122470 & 22756708 & 18365762 & 45.82 & 25.36 & 20.46 \\
\hline 2002 & 9931.45 & 51292334 & 28085051 & 23207283 & 51.65 & 28.28 & 23.37 \\
\hline 2003 & 11675.58 & 70691612 & 37877449 & 32814163 & 60.55 & 32.44 & 28.10 \\
\hline 2004 & 14049.33 & 95750072 & 51540201 & 44209871 & 68.15 & 36.69 & 31.47 \\
\hline 2005 & 16780.12 & 117542900 & 66064400 & 51478500 & 70.05 & 39.37 & 30.68 \\
\hline 2006 & 20401.49 & 165002100 & 99160700 & 65841400 & 80.88 & 48.60 & 32.27 \\
\hline 2007 & 26651.01 & 200954500 & 122842100 & 78112400 & 75.40 & 46.09 & 29.31 \\
\hline 2008 & 33000.07 & 228918900 & 142452200 & 86466700 & 69.37 & 43.17 & 26.20 \\
\hline
\end{tabular}

Data sources: 1981-2008 Provincial Yearbooks

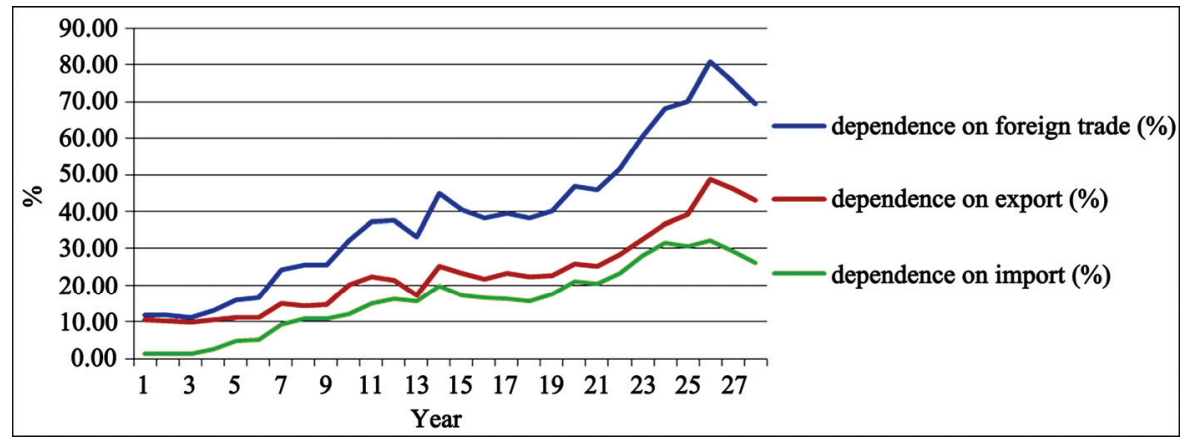

Figure 1. the Trend of dependence of GDP on foreign trade. 


\section{Literature Review}

Economists who concern about foreign trade mainly focus on the effects of foreign trade on national economy, and it has been a focus to discuss the theory about the relationship between foreign trade and economic growth.

It is Adam Smith who first studies the relationship between international trade and economic growth. In his view, the development of division is the principal factor to improve the long-time growth of productivity, and the degree of division is constrained by the scope of market. Expansion of market will naturally deepen the division and improve the productivity, and then improve economic growth; David Ricardo and J. S. Mill as well as D. R. Nurkse all possess the mentioned views shown in their works; while the special dispute starts at Robertson's proposition of that foreign trade is the engine of economic growth (1973) he mainly focus on the theory, which is complemented and developed by Nurkse (the 1950s), that lagging countries can improve their economic growth by foreign trade ,especially, by export growth. He suggests that foreign trade is the crucial factor of economic growth engine.

The engine theory causes controversial disputes [4], many economists suggest that trade growth of developing countries is correlated to their own economic growth, their export growths are constrained by the economic growth of developed countries[5]. William. Lewis is the representative personage of such economists. Irving Kravis (1970) puts forward new viewpoint, which is later accepted by lots of western economists, that foreign trade is a maid of economic growth rather than an engine. Classical school, Marxian school and New classical school all suggest that foreign trade has just indirect impact on accumulation and economic growth, in fact, foreign trade impacts on them through profit margin. Further, some Latin American economists like Prebisch and Singer have completely negative attitude on engine theory, they suggest that in modern global economy regime, developed capitalism countries are the core which is regulating the outer consisting of developing countries, the outer countries must comply with the core countries. This kind of depending relation makes foreign trade the reason of weakening the economy of the developing countries rather than the reason of improving the economy of the developing countries.

Difference of opinions on the relation between foreign trade and economic growth has activated scholars to grope for answers through empirical studies. Such as Jeffrey.Sach and Andrew Warner find that the economic growth rate of those developing countries which carry out opening economies reaches $4.5 \%$, while that of those countries which carry out closed economies only researches $0.7 \%$; in the mean time, they find the economic growth rate of those developed countries which carry out open economies reaches $2.3 \%$, while that of the countries which carry out closed economy only reaches $0.7 \%$.

Some of the scholars mainly focus on co-integration analysis. For instance, Jung and Marshal (1985), Chow (1987), Love (1994), Dhawan and Biswa (1999) have done much of co-integration analyses [6]; Improved methods with error correction model were adopted by some Chinese scholars for doing a lot of empirical studies on trade and economic growth. The empirical analyses done by Shi Chuangyu (2003) and Wang Xianzhu (2007) suggest that growth of export could greatly promote economic growth in short time, while that of import didn't impact economic significancely. Liu Xiaopeng (2001) as well as Li Yuhong and Wang Xiaoyin (2009) do co-integration analyses with the data of import, export and economic, and the results suggests that growth of import greatly promotes economic growth of China, while that of export performs an opposite one;

Some of the scholars mainly focus on contribution ratio of foreign trade. Wei Weixian (1999) drew the conclusion through co-integration analysis and variance analysis that $31 \%$ of economic growth of China ascribes to the export -oriented strategy, while the contribution of economic growth to that of export is less than $10 \%$, this accounts for that the fast growth of China's economic growth doesn't realize the scale effect of the growth of export. Lin Yifu and Li Zhengjun improved the traditional single equation model and built simultaneous equations to calculate the contribution of foreign trade to economic growth. The result suggests that $10 \%$ of the export growth can lead to $1 \%$ of economic growth.

Still, there are many scholars mainly focus on correlation analysis. For instance, Dong Migang (2000) indicated that, in 1978-1998, the correlation of China's foreign trade and economic growth was significant, the coefficient was $r>94 \%$. Guo Xin (2004) drew the conclusion by recursion model, which indicates there exists a significant positive correlation between foreign trade and economic growth. That is to say, the contribution of foreign trade to economic growth is considerable;

While some of the scholars mainly focus on regression analysis to study foreign trade and economic growth. Such as, Yi Xiangshuo (1997) found that the pull effect of export on non-export sectors or the whole economic growth was not strong at all; Yang Quanfa (1998) took a regression analysis with the data (1978-1995) of relevant indexes through the model built by Balasa and Vedur, and he drew a conclusion that growth of export didn't meet the expectation of promoting the economic growth. Sun Lin, Wang Qifan (2003) researched, by the improved Vedur Model, and pointed out that the mechanism and approaches of the effect of China's foreign trade on economic growth has strong time tag.

The above methods all have separate advantages and defects, especially, when single cross-set (time series) 
data analyses are adopted for testing. These methods all have the problem of potential on the low side, and they might lead to errors while calculating long term causalities and the instabilities. In addition, simply dealing with the data is just equal to considering them to be coessential, so their heterogeneity was ignored.

But in this paper, the authors will adopt improved cointegration analysis with error correction model for testing time series data of foreign trade and GDP to research the relationship between foreign trade and GDP growth of east China.

\section{Models and Methods}

Co-integration analysis, which is mentioned above, with time-seriesis is adopted in this paper for testing whether there exists long term or short term stationary causality between foreign trade and GDP growth, and for testing the unit root of each variable to confirm their stationarities. The following would be the desired time-sequence data model [7],

$$
y_{i t}=\rho_{i} y_{i, t-1}+X_{i t} \delta_{i}+\varepsilon_{i t}
$$

where $i=1, \cdots, N$ represent the number of time-series data; $t=1, \cdots, T$ represents time span; $x_{i t}$ are the exogenous variables in the model including fixed effect or time trend of each time-series unit; $\rho_{i}$ is autoregressive coefficient, suppose that disturbance terms $\varepsilon_{i t}$ are mutual independence. If $\left|\rho_{i}\right|<1, y_{i t}$ represents the stationary process; if $\left|\rho_{i}\right|=1, y_{i t}$ represents the process of unit root.

Take the logarithms of the gross domestic products (GDP), total import and export value (IE), total export value (EXP) and total import value (IMP) separately, and they are LnGDP, LnIE, LnIMP, LnEXP. Then test their logarithm values and first difference values through timeseries unit root. Logarithm cited here is for convenience to get stationarity more easily, and is helpful to eliminate the heteroscedasticity of time series and the characteristics of time series and relationships would not be changed.

The relationships between relevant indexes would be tested in this paper by three steps. First of all, test through unit root using time-series data[8]; then, use two-step method put forward by Engle and Granger (1987) to test the mutual long term causalities of relevant indexes; if the long term causality exists, then further test their short term causalities.

\subsection{Test of Time-Series Data by Unit Root}

In order to overcome the deviation brought out by only one method, LLC test, B test and IPS test are all used in this paper to test the relationships between GDP and relevant indexes (IE, EXP and IMP) of foreign trade of east China by unit root.

\subsection{Co-Integration Analysis of Time-Series Data and Long Term Causality Test}

In order to test the long term cassations between variables, two-step test method put forward by Engle and Granger (1987) is used. When measuring the long term causalities between GDP and relevant indexes of foreign trade, the measured variables are mutually simple integrated, and then the regression through the following time-series Equation (1) can be processed. Further, residual errors $E_{i t}$ comes out and it's tested through unit root to determine their stabilities. If $\mathrm{E}_{\mathrm{it}}$ is stationary, the mutual long term causalities are proved to exist.

$$
\operatorname{Ln}(*)=\alpha+\beta \operatorname{Ln}(* *)+\varepsilon_{i t}
$$

where $(*)$ and $(* *)$ separately represent GDP, IE, EXP and IMP.

\subsection{Time-Series Data Error Correcting Model and Short Term Causality Test}

Co-integration relationships just reflect the long term balanced relations between relevant variables. In order to cover the shortage, correcting mechanism of short termdeviation from long term balance could be cited. At the same time, as the limited number of years, the above test result may cause disputes (Christpoulos and Tsionas, 2004). Therefore, under the circumstance of long term causalities, short termcausalities should be further tested as well. The error correcting models could be built as,

$$
\begin{aligned}
& d \operatorname{LnGDP}_{i t}=\eta_{i}+\sum \alpha_{1} d \operatorname{Ln}_{\mathrm{GDP}_{i, t-1}} \\
& +\sum \beta_{1} d \mathrm{LnIE}_{i, t-1}+\lambda \mathrm{ECM}_{i t}+\varepsilon_{i t} \\
& d \mathrm{LnGDP}_{i t}=\eta_{i}+\sum \alpha_{1} d \mathrm{LnGDP}_{i, t-1} \\
& +\sum \beta_{1} d \operatorname{LnEXP}_{i, t-1}+\lambda \mathrm{ECM}_{i t}+\varepsilon_{i t} \\
& d \operatorname{LnGDP}_{i t}=\eta_{i}+\sum \alpha_{1} d \operatorname{LnGDP}_{i, t-1} \\
& +\sum \beta_{1} d \operatorname{LnIMP}_{i, t-1}+\lambda \mathrm{ECM}_{i t}+\varepsilon_{i t} \\
& d \mathrm{LnIE}_{i t}=\eta_{i}+\sum \alpha_{1} d \mathrm{LnIE}_{i, t-1} \\
& +\sum \beta_{1} d \operatorname{LnGDP}_{i, t-1}+\lambda \mathrm{ECM}_{i t}+\varepsilon_{i t} \\
& d \operatorname{LnEXP}_{i t}=\eta_{i}+\sum \alpha_{1} d \operatorname{LnEXP}_{i, t-1} \\
& +\sum \beta_{1} d \operatorname{LnGDP}_{i, t-1}+\lambda \mathrm{ECM}_{i t}+\varepsilon_{i t} \\
& d \operatorname{LnIMP}_{i t}=\eta_{i}+\sum \alpha_{1} d \operatorname{LnIMP}_{i, t-1} \\
& +\sum \beta_{1} d \operatorname{LnGDP}_{i, t-1}+\lambda \mathrm{ECM}_{i t}+\varepsilon_{i t}
\end{aligned}
$$

where $t$ represents year, $d$ rerepresents first difference calculation, $\mathrm{ECM}_{i t}$ represents the errors of long term balance. If $\lambda=0$ is rejected, error correcting mechanism happens, and the tested long term causality is reliable, it 
could be unreliable. If $\beta_{1}=0$ is rejected, and then the short termcausality is not proved to exist.

\section{Result and Analysis}

\subsection{Test of Time-Series Data by Unit Root}

Software Eview 5.0 is herewith used and the four variables LnGDP, LnIE, LnEXP and LnIMP by LLC test, B test, IPS test are calculated and processed separately(see Table 2). The result indicates that LnGDP, LnIE, LnEXP and LnIMP all perform non-stationary state through the tests by the mentioned method. However, after first order difference, through the same methods, it's found that all of them passed the significance test by $1 \%$. So we can say GDP growth, total foreign trade value, total export value and total import value are all integrated of order one.

\subsection{Co-Integration Analysis of Time-Series Data and Long Term Causality Test}

Through the test by unit root, GDP, IE, EXP and IMP all perform one-order simple-integration I (1), there may exist mutual co-integration between relevant variables. The results of their long term causalities and correspondding residual errors $E_{i t}$ can be shown as Table 3 .

From Table 3, it's found that there exists mutual long term causality between LnGDP and LnEXP, two of the three tests (LLC test, B test and IPS test) passed by $90 \%$ significance level. Nothing can prove that there exists long term mutual causality between GDP and LnIMP. Corresponding co-integration equations are the following:

$$
\begin{aligned}
& \operatorname{LnGDP}=6.836721+0.672795 \operatorname{LnEXP} \\
& \text { (28.49411) (45.37549) } \\
& \text { [0.0000] [0.0000] } \\
& \mathrm{F}=2058.395, \mathrm{R}^{2}=0.987530 \\
& \mathrm{LnEXP}=-9.933901+1.467801 \mathrm{LnGDP}
\end{aligned}
$$

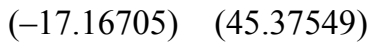

$$
\begin{aligned}
& \text { [0.0000] [0.0000] } \\
& \mathrm{F}=2058.935 \mathrm{R}^{2}=0.987530
\end{aligned}
$$

(Notation: Figures in ( ) and [ ] are separately t-test values and $\mathrm{p}$ values of t-test)

The above equations all passed t-test and F-test by 95\% level. From the co-integration equations, it's clear that, in the long term, LnGDP and Ln EXP are positive. And the elasticity between them is 0.672795 ; this means one unit of LnIE increment will lead to 0.672795 units of LnGDP increment. Similarly, one unit of LnGDP increment will lead to 1.467801 units of LnEXP increment.

\subsection{Time-Series Data Error Correcting Model and Short Term Causality Test}

It's found, according to the co-integration test of time-series data, that there exist mutual long term causality between LnGDP and LnEXP. For the limited number of years, short causality between them should be used to test their stationarities (see Table 4).

The result in Table 4 states the following clear: ECM in model 1, of which test equation is Equation (6), is positive and passes the test by 0.05 level, indicating cor-

\begin{tabular}{|c|c|c|c|c|c|c|c|c|}
\hline \multirow{2}{*}{$\begin{array}{c}\text { Time span: } \\
28\end{array}$} & \multicolumn{2}{|c|}{ LnGDP } & \multicolumn{2}{|c|}{ LnEXP } & \multicolumn{2}{|c|}{ LnIMP } & \multicolumn{2}{|c|}{ LnIE } \\
\hline & Level test & first difference & Level test & first difference & Level test & first difference & Level test & first difference \\
\hline ADF test & $\begin{array}{l}2.1999 \\
(0.999)\end{array}$ & $\begin{array}{c}-4.2547 * * \\
(0.0028)\end{array}$ & $\begin{array}{l}2.2935 \\
(0.999)\end{array}$ & $\begin{array}{c}-4.1016^{* *} \\
(0.0040)\end{array}$ & $\begin{array}{c}-2.902 * \\
(0.059)\end{array}$ & $\begin{array}{c}-3.7241 * * \\
(0.0085)\end{array}$ & $\begin{array}{l}1.0197 \\
(0.996)\end{array}$ & $\begin{array}{c}-4.5716^{* *} \\
(0.0013)\end{array}$ \\
\hline PP test & $\begin{array}{l}7.4563 \\
(1.000)\end{array}$ & $\begin{array}{c}-4.2076^{* *} \\
(0.0031)\end{array}$ & $\begin{array}{l}2.2935 \\
(0.999)\end{array}$ & $\begin{array}{c}-4.0796 * * \\
(0.0042)\end{array}$ & $\begin{array}{l}-1.701 \\
(0.418)\end{array}$ & $\begin{array}{c}-4.0464 * * \\
(0.0045)\end{array}$ & $\begin{array}{l}-1.001 \\
(0.995)\end{array}$ & $\begin{array}{c}-4.5902 * * \\
(0.0012)\end{array}$ \\
\hline
\end{tabular}
recting error mechanism happens, and long term pull effect of export trade on GDP has been proved. ECM in model 6 is also positive and passes the test by 0.05 levels, further indicating that export always promote GDP to

Table 2. Result of Time-series data test by unit root.

Notation: 1) the Figures in the brackets are p values; 2) *indicates panel data pass of the significance test by $95 \%$ level, $* *$ indicates panel data pass of the significance test by $99 \%$ level; 3 ) testing form is only intercept, lagging exponent number is chosen as Schwarz rules.

Table 3. Result of Time-series Co-integration test (test of residual errors by unit root).

\begin{tabular}{lll}
\hline \multicolumn{1}{c}{ Variables } & ADF test & PP test \\
\hline LnGDP is the induced variable of LnIE & $-1.6497(0.4444)$ & $-1.5748(0.4813)$ \\
LnIE is the induced variable of LnGDP & $-1.8836(0.3345)$ & $-1.8023(0.3714)$ \\
LnGDP is the induced variable of LnIMP & $-0.9914(0.7416)$ & $-1.3153(0.6075)$ \\
LnIMP is the induced variable of LnGDP & $-1.9525(0.3047)$ & $-2.0177(0.2779)$ \\
LnGDP is the induced variable of LnEXP & $-2.9299 *(0.0550)$ & $-2.8616^{*}(0.0632)$ \\
LnEXPis the induced variable of LnGDP & $-2.9830^{* *}(0.0493)$ & $-2.9036^{*}(0.0581)$ \\
\hline
\end{tabular}

Notation: *indicates panel data pass of the significance test by $95 \%$ level, **indicates panel data pass of the significance test by $99 \%$ level. 
Table 4. Short term causality test of Time-series data.

\begin{tabular}{cccccccc}
\hline variable & & $\mathrm{C}$ & $\mathrm{D}(\operatorname{LnGDP}(-1))$ & $\mathrm{D}(\operatorname{LnIEXP}(-1))$ & $\mathrm{ECM}$ & $\mathrm{R}^{2}$ & Fvalue \\
\hline \multirow{2}{*}{ Model 3 } & $\mathrm{D}($ LnGDP $)$ & 0.03429 & -0.149232 & $0.621686^{* *}$ & $0.3342^{*}$ & 0.451 & $60022^{* *}$ \\
& & $(0.2906)$ & $(0.3971)$ & $(0.0000)$ & $(0.056)$ & $(0.03726)$ & \\
\multirow{2}{*}{ Model 6 } & $\mathrm{D}(\operatorname{LnEXP})$ & $0.130995^{* *}$ & 0.196343 & 0.188206 & $0.3755^{* *}$ & 0.341 & $3.80176^{* *}$ \\
& & $(0.0011)$ & $(0.3233)$ & $(0.3287)$ & $(0.0053)$ & $(0.02457)$ \\
\hline
\end{tabular}

Notation: *indicates panel data pass of the significance test by $95 \%$ level, **indicates panel data pass of the significance test by $99 \%$ level.

grow, and it's passed F-test, so it's concluded that export trade and GDP are mutually causal.

\section{Conclusions and Recommendations}

The result of the tests indicates foreign trade is the long term and short termsource of GDP growth of east China. Total export has positive relationship with GDP growth, and they are mutually causal. It has proved the intuitional dependence relationship mentioned in part 1 (INTRODUCTION). Developing foreign trade is good for promoting GDP growth of east China, and GDP growth, in reverse, is also good for promoting the development of open economy. No evidence can prove that there exists long term stationary causality between import and GDP growth as well as that between total foreign trade and GDP; it's not necessary that import can directly contribute to GDP growth. As the crowding-out effect of imported products from foreign countries and the indirect promoting effect couldn't be measured, it cannot be proved either there exists long term causality between import and GDP, or there exists long term stationary internal logical causality .

According to the empirical study results, strong development of foreign trade greatly benefits the economic development in east China. To overcome the problems existed in foreign trade, for the current financial crisis and hard retrieve of global economy, and in order to reduce its corresponding economic loss as much as possible, keeping scale of exports is necessary. Thus, governments of all levels in east China should do as the following:

1) Stable exchange rate must be remained. At present, RMB can not be continuously upvalued, and in the long run, it could be devalued. Then it can be helpful to keep or even improve the competitiveness of the products there. Furthermore, it will be good to enrich the commodities to increase export supply.

2) Active industrial policy must be carried out. First, develop hi-tech industries, improve the comparative advantages of the products as well as the competitiveness; Second, develop specialty industries to amplify the comparative advantages to increase exports; Third, cultivate emerging industries, through importing FDI and high technologies, to improve own productivity. That is to say, governments should make great efforts to the construc- tion of export by virtue of a series of industrial restructuring and revitalization, and to the plans continuously introduced by the state in textile, steel, automobile, equipment manufacturing industries. Develop high-tech and echo-friendly products, promote the exports of branded products, and large machinery, complete sets of equipment as well as edge and labor-intensive products to support tech innovation in small and medium enterprises so as to increase competitiveness.

3) Strategic trade policy must be performed. First, choose special industries in east China to protect or provide with subsidies to possess bigger share of global market [9]. Some labor-intensive products, like textile products, have less profit for their lower prices, so subsidies can keep their irreversed benefits to some extent, and laborintensive industries can improve employments; Second, protect domestic market to protect and cultivate emerging industries, and finally increase exports; Third, take advantages of the increased export rebate rate of some products introduced by the states, and improve the upgrade and transformation of the trade in processing.

4) Pro-active fiscal policy should be executed in east China. Governments of all levels should provide the enterprises with more capital supports to improve the financial environment for exportation and financing for the enterprises. Meanwhile, stepping up their supports for entrepreneurs' credit and improving secured financing conditions are of great importance. However, preferential policies, such as lower income tax and sales tax, also could be provided to support and promote the border trade as well as international trade. And the governments should increase investment in port construction, market developpment, project declaration, utilization of funds and joint inspection service to help exports, and increase expenditure to bring in and cultivate talents in foreign trade by training the employers' ideas, practical abilities, knowledge and negotiation skills etc, in order to improve their capability of service and creation.

5) Trade protection must be always aware of under current hard retrieve of global economy. With the wide spread of the international financial crisis, all kinds of trade protectionism, in the form of technique protection, green products standard, anti-dumping, countervailing etc, in countries across the world are getting rampant. In a word, trade barriers are set for many excuses to reduce import, which has become a prescription for some countries to 
get rid of crisis. Therefore, governments in east China must be highly aware of it and ready to face provocation of protectionism in foreign trade.

\section{Acknowledgements}

This paper is assisted by the projects: Jiangxi provincial Co-operated Social Science Projects, A Study on the Development of Service Industry and Trade in Service in Jiangxi Province (Project ID: 09YJ249)and A Research on the Evolution of the Spatial Economy in Jiangxi and Agglomeration of Industry (Project ID: 09YJ245); A Study on the Development of Logistics in Ji'an City Based on the Theory of Industry Cluster (Project ID: JR0816).

\section{References}

[1] Y. H. Li and X. Y. Wang, "Research on the Relationship between Foreign Trade and the GDP Growth of Southwest Minority Region of China-Empirical Analysis Based on the Panel Causality," IEEE International Conference on Industrial Engineering and Engineering Management, Hongkong, December 2009, pp. 798-802.

[2] Y. H. Li and K. Y. Deng, "An Empirical Study on the
Contribution of Foreign Trade to the Economic Growth of Southwest Minority Region of China," International Conference on Computational Intelligence and Software Engineering, Wuhan, December 2009, pp. 1-4.

[3] A. Levin, C.-F. Lin and C. Chu, "Unit Root Tests in Panel Data: Asymptotic and Finite Sample Properties," Journal of Econometrics, Vol. 108, No. 1, 2002, pp. 1-24.

[4] J. Love, "Engines of Growth: the Exports and Government Sectors," World Economy, Vol. 17, No. 2, 1994, pp. 203-218.

[5] W. S. Jung and P. J. Marshall, "Export, Growth and Causality in Developing Countries," Journal of Development Economics, Vol. 18, No. 2, 1985, pp. 1-12.

[6] P. C. Y. Chow, "Causality between Export and Industrial Development: Empirical Evidence from NICs," Journal of Development Economics, Vol. 26, No. 1, 1987, pp. 5563.

[7] C. Kao, "Spurious Regression and ResiduaL2based Tests $\mathrm{f}$ or Co-integration in Panel Data," Journal of Econometrics, Vol. 90, No. 1, 1999, pp. 1-44.

[8] K. S. Im, H. Pesaran and Y. Shin, "Testing f or Unit Roots in Heterogeneous Panels," Journal of Econometrics, Vol. 115, No. 1, 2003, pp. 53-74.

[9] E. Helpman and P. R. Krugman, "Market Structure and Foreign Trade," MIT Press, Cambridge, 1985. 